\title{
David Oliver: Time for an honest patient's charter?
}

\author{
David Oliver consultant in geriatrics and acute general medicine
}

Berkshire

The parliamentary act that led to the NHS's creation set out what the public could expect-a universal service based on need, free at the point of delivery. ${ }^{1}$ Since then, the government has repeatedly set out standards that the public should expect.

We had John Major's “patient's charter,"” then NHS standards for four hours in emergency departments or two weeks for investigation of suspected cancer. ${ }^{3}$ The NHS constitution strengthened the founding principles. ${ }^{4}$ The government response to the Francis inquiry guaranteed fundamental standards of care. ${ }^{5}$ The Care Quality Commission explicitly inspects services for "responsiveness." The current government has promised the same quality of care across all seven days. ${ }^{6}$

Such promises are a kind of government contract with the people: "Elect us, pay your taxes, and in return this is what you can expect the NHS to provide." I welcome them, when they have a realistic chance of delivery.

I also welcome continued high levels of public pride in the NHS and decent levels of user satisfaction. ${ }^{78}$ I welcome the consistent rating of the NHS as one of the most equitable, fee-free, and efficient health services in the world. And it's miraculous that we continue to deliver so well on national waiting time targets, such as those for emergency departments.

Some of the unhappiness stems from expectations we can't reliably meet and should perhaps stop promising

But there's no denying that plenty of patients and families are unhappy - even if many don't formally complain — and no shortage of journalists, phone-in callers, or web commentators describing unhappy personal or family experiences of the system.

NHS key performance indicators are worsening in the face of funding shortfalls, workforce gaps, and unprecedented demand, as the King's Fund's latest quarterly monitoring report shows. ${ }^{9}$ Some of the unhappiness stems from expectations we can't reliably meet and should perhaps stop promising.

More people are waiting longer in seriously overcrowded emergency departments. ${ }^{9}{ }^{10}$ More are stranded in acute beds, waiting for social or community health services. ${ }^{11}$ Many feel rushed out from scarce acute beds, with wider system pressures perforce taking priority over individual needs. ${ }^{12}$ More planned procedures are being cancelled or delayed: waiting lists have reached nearly four million this year. ${ }^{13}$

Nurses on very short staffed wards may struggle to find time to care, and morale suffers. ${ }^{14}$ Therapist hours aren't always enough for anything beyond basic rehabilitation. ${ }^{15}$

Maybe it's time for a new, realistic patient's charter, honest about current constraints. Instead, we have grand, government driven promises to maintain performance and expand access - promises it will struggle to keep. ${ }^{16}{ }^{17}$

In a contract, you're meant to get what you pay for. As NHS England's chief executive, Simon Stevens, recently admitted, we're no longer paying enough. ${ }^{18}$

Competing interests: See www.bmj.com/about-bmj/freelancecontributors/david-oliver.

Provenance and peer review: Commissioned; not externally peer reviewed.

The UK National Health Service Act of 1946. Pittsburgh Post-Gazette 2010 Apr 29. http: //old.post-gazette.com/pg/10119/1054305-114.stm.

2 Patient's charter blamed for attacks on NHS staff. BBC Health 1998 Oct 28. http://news. bbc.co.uk/1/hi/health/202942.stm.

3 King's Fund. Have targets improved NHS performance? 2010. https://www.kingsfund.org uk/projects/general-election-2010/key-election-questions/performance-targets.

4 NHS England. The NHS constitution: the NHS belongs to us all. $27 \mathrm{Jul} 2015$. https://www. gov.uk/government/uploads/system/uploads/attachment_data/file/480482/NHS Constitution_WEB.pdf.

5 Department of Health. Patients first and foremost: the initial government response to the report of the Mid Staffordshire NHS Foundation Trust public inquiry (Cm 8576). Mar 2013. https://www.gov.uk/government/uploads/system/uploads/attachment_data/file/170701/ Patients_First and Foremost.pdf.

6 Nuffield Trust. Spotlight on: seven-day NHS. www.nuffieldtrust.org.uk/summit/spotlightseven-day-nhs?gclid=CIP_wNGbptACFRAzOwodCvgPjw.

7 Quigley A. Maintaining pride in the NHS: the challenge for the new NHS chief exec. Ipsos MORI. 2014. https://www.ipsos-mori.com/newsevents/blogs/makingsenseofsociety/1553/ Maintaining-pride-in-the-NHS-The-challenge-for-the-new-NHS-Chief-Exec.aspx.

8 Appleby J, Robertson R. Public satisfaction with the NHS in 2015. King's Fund. 9 Feb 2016. https://www.kingsfund.org.uk/projects/public-satisfaction-nhs/bsa-survey-2015.

9 King's Fund. Quarterly monitoring report. How is the NHS performing? Sep 2016. http:// qmr.kingsfund.org.uk/2016/20/.

10 Blunt I. Nuffield Trust, Health Foundation, QualityWatch: focus on A\&E attendances-why are patients waiting longer? Jul 2014. www.nuffieldtrust.org.uk/sites/files/nuffield/ publication/140724 focus on ae attendances.pdf.

11 Oliver D. More older patients are stuck in hospitals. BMJ 2016;353:i2948. doi:10.1136/ bmj.i2948 pmid:27230037.

12 Healthwatch England. Safely home: what happens when people leave hospital and care settings? Jul 2015. www.healthwatch.co.uk/sites/healthwatch.co.uk/files/170715_ healthwatch_special_inquiry_2015_1.pdf. 
13 Campbell D. NHS "in perpetual winter of Narnia" as waiting list reaches record $3.9 \mathrm{~m}$. Guardian 2016 Sep 8. https://www.theguardian.com/society/2016/sep/08/nhs-perpetualwinter-waiting-list-record-bed-blocking

14 Ball JE, Murrells T, Rafferty AM, Morrow E, Griffiths P. 'Care left undone' during nursing shifts: associations with workload and perceived quality of care. BMJ Qual Saf 2014;23:116-25. doi:10.1136/bmjqs-2012-001767 pmid:23898215.

15 Hubbard RE, O'Mahony MS, Cross E, et al. The ageing of the population: implication for multidisciplinary care in hospital. Age Ageing 2004;33:479-82. doi:10.1093/ageing/ afh164 pmid:15292034

16 Dunhill L. Revealed: NHS England checklist for making STP details public. Health Serv J 2016. https://www.hsj.co.uk/topics/service-design/revealed-nhs-england-checklist-formaking-stp-details-public/7011455.article
17 Data.parliament. Written evidence submitted by Chris Hopson, CEO of NHS Providers, to Health Select Committee (FIN0003). 6 Oct 2016. http://data.parliament.uk/ writtenevidence/committeeevidence.svc/evidencedocument/health-committee/departmentof-health-and-nhs-finances/written/40440.html.

18 Rimmer A. Public "will have to put their hands in their pockets" for better NHS, Stevens says. BMJ 2016;355:i6069. doi:10.1136/bmj.i6069 pmid:27836887.

Published by the BMJ Publishing Group Limited. For permission to use (where not already granted under a licence) please go to http://group.bmj.com/group/rights-licensing/ permissions 